\title{
Niceness Is Not Enough
}

\author{
A Response Welch \\ Derek Gottlieb \\ University of Northern Colorado
}

Kirsten Welch has done an excellent job of shining a light on the paltriness and inadequacy of a region of moral language typified by the idea of "niceness." She takes issue with the "thinness" of the term, which makes it a kind of blank slate capable of accommodating any particular content (and so prescribing nothing in particular), and which, by the same token allows it to quash any particular claim of injustice. With Alisdair MacIntyre prominently in the background - and the foreground - of her argument, she attributes the preference for something like niceness to liberal pluralism's absence of a shared tradition and the co-occurring impermissibility of imposing moral frameworks on others. With the emptiness of "niceness" on one side and the rightful worry about indoctrination on the other, Welch proposes that teachers can help students come to a more robust moral vocabulary through the "attention to narrative and story."

This is an excellent paper, insightful about the dangers posed by superficial moral language and the difficulties of sharing a moral life under the conditions of liberal pluralism. I am less sanguine than Welch about the ability to draw lines between "thin" and "robust" examples of moral vocabulary, and I am similarly less sanguine about the ability of story or narrative to skirt issues of indoctrination, but with these differences articulated, I would like to characterize my response in terms of the "Yes, and" genre, thinking through Welch's paper with the assistance of Wittgenstein and Cavell, though the latter will appear mostly as an inspiration.

Welch's critique of the "reign of niceness" and her suggestion that we reinvigorate our moral language by attending to narrative seems to owe a great deal to MacIntyre's view of what is lost when liberal pluralism takes the place 
of a shared moral tradition. MacIntyre's basic worry, as I read him in After Virtue, especially, is that liberalism's rejection of a teleological view of human life and the simultaneous valorization of the individual makes a public moral life impossible. Moral concepts are necessarily wedded to a view of the aims of human life, and if this purpose is only properly decidable at the individual level, then it becomes inappropriate to so much as enter moral claims in the public sphere. Moreover, even if one were to enter claims publicly, in violation of the spirit of pluralism, this moral language would carry little weight, since the power of moral compulsion derives from the commonness of the shared tradition.

On this view of modern liberal pluralism, we are malingering in something like a parody of a moral life. We can still use moral terminology, but, just as Welch points out with the example of niceness, we prefer maximum generality, which is to say maximum emptiness. To use more robust language is to risk indoctrination, particularly where teachers' relations to their students are concerned. MacIntyre took Rawls to task for abdicating the moral field, but the setup here, with indoctrination on one side and vacuity on the other, looks a lot like Rawls's own theater of public reason, governed precisely by his method of avoidance.

This is to say that Welch's MacIntyre shares with Rawls, ironically, a certain view of what a shared tradition would do (and has historically done) for public morality and thus what the absence and refusal of such a tradition means. I think this view itself is wrong, or anyway underdeveloped, and so the consequences of and possible solutions to the situation are likewise askew. Welch's "reign of niceness" is an astute take on our cultural response to our pluralistic situation, but I want to suggest that it is illustrative not of a retreat from moral language as such - that is, what makes niceness insufficient would not be solved by substituting something like "benevolence" - but of a certain refusal to dirty our hands with the public morality that nevertheless remains. This may seem like a subtle and unimportant distinction, but it is the difference between publicly lacking a shared moral tradition and publicly disowning the moral life that we do, still, in fact, share. The distinction matters because Welch's best solution directing attention to narratives to flesh out moral concepts - is the right one, 
but it can't be the right one if MacIntyre's diagnosis of the problem is correct.

Let me briefly clarify that point before taking on MacIntyre's diagnosis itself. If pluralism rejects the possibility of grounding moral life - and a moral language - on a common tradition, such that to use any robust moral terminology in the public sphere is to impose an idiosyncratic moral framework on another who ought to be free to choose their moral direction for themselves, then pointing to or drawing attention to specific aspects of any narrative, as Welch (and MacIntyre) suggest(s), is just a different form of this same imposition. Certain Christian groups, for example, have risen up in arms at the inclusion of Harry Potter novels on school reading lists because they feared that the books were normalizing witchcraft. " 1 Participating with... students in attention to narrative and story" therefore only avoids indoctrination fears to the extent that we are pointing to the right stories, the right narratives. And since pluralism assumes that we cannot agree on this issue, narrative and story recapitulate rather than solve the terminology problem.

Fortunately, the indoctrination worry itself is overblown because MacIntyre's view of the difference between liberal pluralism and a moral monoculture overvalues the determinative capacity of any tradition and underestimates the difficulty of sharing of any tradition. For MacIntyre, as for Rawls, traditions stabilize communities by clearly dictating to adherents what ought to be done in any particular situation. Admitting competing traditions into communities is therefore destabilizing because many paths are suddenly open when a given situation presents itself.

But is this true? Has the existence of a moral tradition ever been sufficiently constraining when it comes to moral direction, even among those who share it? The history of the Abrahamic faiths suggests that moral community is a matter of shared interpretations at least as much as it is a matter of shared rules-what Wittgenstein called "agreement in judgments" as opposed to "agreement in opinion." ${ }^{2}$ A shared moral tradition, imagined as a shared rulebook, is not as stabilizing as Welch's MacIntyre thinks. ${ }^{3}$

Nor, for the same reason, is pluralism as inherently destabilizing as Welch's 
MacIntyre thinks. Communities must still live public lives, which requires a deep form of agreement - again, what Wittgenstein calls agreement in form of life. We can disagree on whether the moral concept of modesty requires headscarves while still sharing an understanding of what modesty is and why it is morally valuable. Indeed, in order to disagree on any moral concept, we have to simultaneously agree on so much else: we have to be mutually intelligible in our language, in our distance-standing practices, even roughly in our estimation of the value of the moral dimension itself. Agreeing with another that this is what ought to be done in this situation was never simply produced by an agreed-upon rulebook, or even, as if mechanically, by what moral exemplars have done in the past. It was produced by attuning ourselves to one another, by sharing examples and exercises, as Wittgenstein suggests: this includes correctly projecting examples into the future, a kind of learning that "points beyond" the examples given. ${ }^{4}$

Now I can say all this more simply: MacIntyre worries that in the absence of a shared, transcendent tradition we are each left to our own Hobbesian devices or else forced to violate the terms of our pluralistic public sphere and tyrannically indoctrinate one another into our own moral system. But moral traditions have never actually been transcendent, really; they have always been embodied and personal. We have always learned how to follow a given rule, and which rules are worth following, from the examples of admirable others. Sharing a moral life is difficult precisely because it is personal, because attempts to lead by example, or to follow an example in a novel situation, are subject to failure or rejection. ${ }^{5}$ Sharing an explicit fealty to a particular moral code simply masks this difficulty. Pluralism simply lays the difficulty bare.

Let's interpret "the reign of niceness" from this perspective, by way of closing. Welch correctly and incisively notes that niceness appeals to us under the conditions of pluralism for one principal reason: its thinness, its ambiguity. Because it is not tethered to any particular action in any particular situation, it gives us cover - license - to take any action without seeming to traduce our (vacant) moral code. It similarly allows us to stifle substantive moral protest without equally substantive engagement. The very many instances of white people suggesting that they support the Movement for Black Lives' right to 
protest, only not like that, are essentially accusing the Movement of violating "niceness" standards, and the accusation functions as a way of refusing to hear their actual claims.

The valorization of niceness is a refusal of moral responsibility, just as Welch indicates. But it is a refusal of personal responsibility to exemplify a moral way of life that others might share and to follow the moral examples of others in finding one's own way. Simply pointing to the shared rulebook, however, would amount to a similar refusal. Pluralism requires that we put ourselves vulnerably at stake, knowing that our example might fail to compel, or our attempt to act as another would act might turn out to be wrong. "Being nice," as an aspiration and a form of admonition, is doubly damning because it refuses one's moral responsibility while seeming to discharge it. That, I take it, is Welch's central point, and I want to end by applauding it.

1 Javier Espinoza, "Religious parents want Harry Potter banned from the classroom because it 'glorifies witchcraft," Telegraph, December $15^{\text {th }}, 2015$, https://www.telegraph.co.uk/education/educationnews/12052212/Religious-parents-want-Harry-Potter-banned-from-the-classroom-because-it-glorifies-witchcraft.html

2 Wittgenstein, Ludwig. Philosophical Investigations, trans. Joachim Schulte, P. E.

S. Hacker, G. E. M. Anscombe (London: Wiley-Blackwell, 2009), 241.

3 I am indebted to David Hansen for pointing out in the session that despite the fact that the setup is similar, MacIntyre's virtue ethics is a much more substantive response than Rawls's notion of pubic reason - it is not a shared rulebook, but the sharing of virtues via overlapping practices; these practices are reinforced in our narratization of our own lives and reflected in narratives we consume publicly. This still leaves intact the suggestion that pointing to certain narratives recapitulates the indoctrination problem Welch astutely 
identifies, but it's more faithful to MacIntyre than conflating his solution with a Rawlsian rulebook.

4 Ludwig Wittgenstein, Philosophical Investigations (London: Wiley-Blackwell, 2009), 208.

5 This is really where the Cavellian inspiration comes in. 